\title{
Roy Turkington and his legacy to the science of plant ecology
}

\author{
Lauchlan H. Fraser · James F. Cahill · Christopher J. Lortie
}

Published online: 27 September 2016

(C) Springer Science+Business Media Dordrecht 2016

\section{Introduction}

Roy Turkington, Tibetan Plateau, Qinghai Province, China. Photo: L Fraser

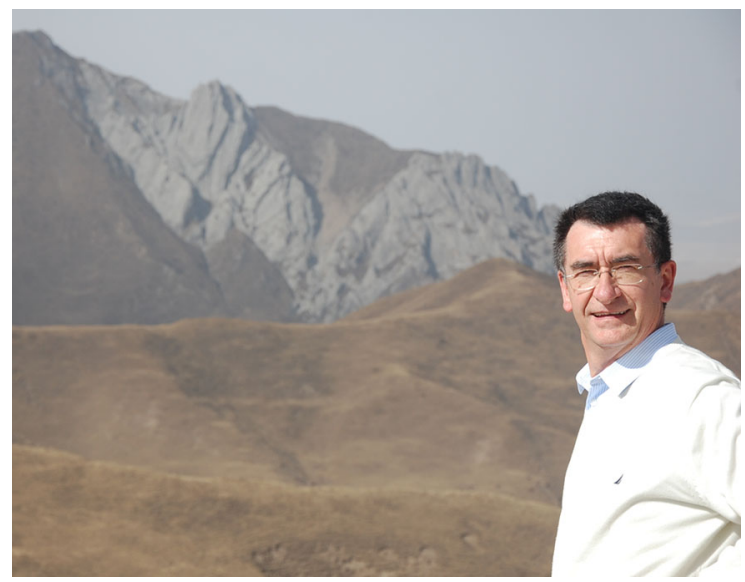

L. H. Fraser $(\bowtie)$

Department of Natural Resource Sciences, Thompson Rivers University, Kamloops, BC, Canada e-mail: 1fraser@tru.ca

\section{J. F. Cahill}

Department of Biological Sciences, University of Alberta, Edmonton, AB, Canada

\section{J. Lortie}

Department of Biology, York University, Toronto, ON, Canada

e-mail: lortie@yorku.ca
Plant ecology is de facto the study of plants-how plants establish, grow, compete, persist, defend themselves, and reproduce within the environments in which they are found. Considering the fact that all plants have a short list of basic requirementssunlight, nutrients, and water-it is amazing that so many words are written, papers published, so many books bound, and studies conducted on the subject, and with no end in sight. However, perhaps not so surprising given that sunlight can be partially shaded and blocked (Givnish 1988), the stoichiometry of nutrients is multi-dimensional (Güsewell 2004), water availability is variable in time and space (Weltzin et al. 2003), and plants have adapted in multiple ways to defend themselves (Stamp 2003). In other words, even with so few essential elements, the life of a plant is complex and rich (Harper 1967).

It takes a keen and passionate mind to disentangle the complexity of plant ecology and to focus on clearly defined and testable questions. Moreover, it takes a very special person to share that passion and pass along those skills to the next generation. Professor Roy Turkington embodies these characteristics, and in this special issue we pay tribute to Roy and his legacy to the science of plant ecology.

Roy Turkington, a Northern Irishman, began his academic career at the New University of Ulster in Coleraine where he received his BSc in 1972, followed by a PhD in 1975 under the supervision of Professor John Harper at Bangor University. John Harper, an eminent plant ecologist, had a lifelong influence on 
Roy's career, and Roy wrote John Harper's obituary for the British Ecological Society (Turkington 2009).

After receiving his $\mathrm{PhD}$, Roy and his wife Evelyn left for Canada to a postdoctoral position with Professor Paul Cavers, also a former Harper student, at the University of Western Ontario. Shortly afterwards, The University of British Columbia's (UBC) Botany Department advertised for a tenure track field ecologist and Roy was awarded the position in the fall of 1977. At UBC, Roy developed a remarkable 37-year career through to his recent retirement in June 2015. During his time at UBC, Roy published over 120 peer-reviewed articles, many in the top-tiered journals in ecology, which were consistently funded by Canada's federal science funding agency, the Natural Sciences and Engineering Research Council; pursued research projects in Canada, the United States of America, the United Kingdom, Israel, Kenya, and China; and taught thousands of undergraduate students the science and the joys of plant ecology.

Roy has contributed to many different sub-disciplines within the field of plant ecology, from plant traits to populations, communities, and ecosystems, with the most significant impacts being in the areas of competition and community structure. From his competition research, Roy took a 'plant-eye-view', or Darwinian perspective. One of the papers Roy published with John Harper based on his $\mathrm{PhD}$ dissertation (Turkington and Harper 1979) was recognized as "one of the top 100 most influential papers published by the British Ecological Society (1913-2012)" as part of the BES centenary celebrations. The paper demonstrated for the first time that biotic interactions between neighbours influence selective pressure on competitive ability and plant performance. Lonnie Aarssen and Loyal Mehrhoff, PhD students under Roy's supervision, followed this line of research and Roy and Loyal contributed a chapter to Perspectives on Plant Competition, a collection edited by David Tilman and James Grace that remains influential to this day as a reference and guide for future research (Turkington and Mehrhoff 1990). Recent research conducted by another of Roy's former PhD student's, Andrew MacDougall, tested whether dominant invasive species are driving community change or are "passengers along for the environmental ride" (MacDougall and Turkington 2005). They examined the relative importance of competition and dispersal limitation with experimental seed additions within a controlled disturbance design that included mowing and weeding. Their conclusion, that the passenger model best explained exotic dominance, has resulted in a new line of research in biological invasion theory.

In light of Roy's notable academic achievements, perhaps Roy's biggest legacy to the science of plant ecology is the mentorship he has provided to the many graduate students that have populated his lab (Table 1). Roy is a true mentor, providing guidance and support to all of the people who have migrated through his lab. He has lent his skills and his labour from the experimental fields in Abbotsford, British Columbia (BC) to Port Hardy, BC, to Victoria, BC; from Kluane in the Northwest Territories to the Negev desert in Israel; and more recently, in the oak forests of southeastern China. Roy has a knack for getting the best out of his graduate students and postdoctoral fellows, which is reflected in their accomplishments today. Roy's former students can be found in faculty positions across Canada, the USA, and the UK.

Roy is a storyteller, which students love, because they can relate to the real events and real people that are behind the experiments and theories that contribute to the science of ecology. While students were wrapped up in the stories that Roy shared while teaching, they also often found themselves riveted to Roy's balancing act as he perched his feet, half on and half off, while teetering back and forth on the edge of the lecture hall stage six feet in the air, as he talked. He never fell, likely because of his athletic ability; a champion track star in his youth, he now wins medals at sprinting and long jump events at senior meets across Canada.

We took this opportunity to celebrate Roy's career on his retirement. On 30 June 2015, a special symposium was held at UBC involving a full day of original research talks and reminiscences from his former students and colleagues (Fig. 1). Here, we have collected the original research into a Special Issue, reflecting the many interests that spurred Roy's career.

This Special Issue is separated into two main themes: (1) Plant traits and population dynamics and (2) Community structure. For the first theme, we start with a paper that investigates factors that determine plant trait similarity (Fraser et al. 2016). The second is a focused study of plant traits of the invasive Heterotheca subaxillaris along its geographic range (Sternberg 2016). The third paper defines and tests a 
Table 1 Student theses published under the supervision of Roy Turkington at the University of British Columbia, Department of Botany

\begin{tabular}{|c|c|c|c|}
\hline Name & Year & Title & Degree \\
\hline Aarssen, L.W. & 1983 & Interactions and coexistence of species in pasture community evolution. & $\mathrm{PhD}$ \\
\hline Ratcliffe, M.J. & 1983 & $\begin{array}{l}\text { Interspecific associations, phenology, and environment of some Alpine plant } \\
\text { communities on Lakeview Mt., southern British Columbia. }\end{array}$ & MSc \\
\hline Evans, R.C. & 1986 & $\begin{array}{l}\text { Morphological variation in a biotically patchy environment: evidence from a } \\
\text { pasture population of Trifolium repens L. }\end{array}$ & MSc \\
\hline Parish, R. & 1987 & The role of disturbance in permanent pastures & $\mathrm{PhD}$ \\
\hline Chanway, C.P. & 1987 & Plant/bacteria coadaptation in a grass/legume pasture & $\mathrm{PhD}$ \\
\hline Mehrhoff, L.A. & 1989 & $\begin{array}{l}\text { The evolutionary consequences of interactions between plants in permanent } \\
\text { pastures }\end{array}$ & $\mathrm{PhD}$ \\
\hline Fraser, L.H. & 1993 & $\begin{array}{l}\text { The influence of salal on planted hemlock and cedar saplings on northern } \\
\text { Vancouver Island. }\end{array}$ & MSc \\
\hline Graham, S.A. & 1994 & $\begin{array}{l}\text { The relative effects of clipping, neighbours and fertilization on the } \\
\text { population dynamics of Lupinus arcticus (Family Fabaceae) }\end{array}$ & MSc \\
\hline Marcuvitz, S. & 1994 & $\begin{array}{l}\text { The effects of light conditions from patchy natural canopies on the growth } \\
\text { and morphology of white clover clones }\end{array}$ & $\mathrm{PhD}$ \\
\hline Dlott, F. & 1996 & $\begin{array}{l}\text { Components of regulation of boreal forest understory vegetation: a test of } \\
\text { fertilizer and herbivory }\end{array}$ & MSc \\
\hline Arii, K. & 1996 & $\begin{array}{l}\text { Factors restricting plant growth in a boreal forest understorey: a field test of } \\
\text { the relative importance of abiotic and biotic factors }\end{array}$ & MSc \\
\hline Sharam, G. & 1997 & $\begin{array}{l}\text { Secondary defense responses in white spruce (Picea glauca) and Arctic } \\
\text { lupine (Lupinus arcticus) to changes in herbivory and soil nutrient } \\
\text { concentrations }\end{array}$ & MSc \\
\hline Hicks, S.L. & 1997 & $\begin{array}{l}\text { Compensatory growth of three herbaceous perennial species: the effect of } \\
\text { clipping and nutrient availability }\end{array}$ & MSc \\
\hline Seccombe-Hett, P. & 1999 & Summer diet selection by snowshoe hares & MSc \\
\hline Lortie, C.J. & 2001 & Net interactions in an annual plant community in the Negev desert, Israel & $\mathrm{PhD}$ \\
\hline MacDougall, A.S. & 2004 & $\begin{array}{l}\text { Joint effects of competition, recruitment limitation, and fire suppression in an } \\
\text { invaded oak savanna ecosystem }\end{array}$ & $\mathrm{PhD}$ \\
\hline Sharam, G. & 2005 & $\begin{array}{l}\text { The decline and restoration of riparian and hilltop forests in the Serengeti } \\
\text { National Park, Tanzania }\end{array}$ & $\mathrm{PhD}$ \\
\hline Karst, J.D. & 2007 & $\begin{array}{l}\text { Sensitivity in growth responses of tree seedlings to variation in identity and } \\
\text { abundance of ectomycorrhizal fungi }\end{array}$ & $\mathrm{PhD}$ \\
\hline Treberg, M.A. & 2007 & $\begin{array}{l}\text { Community- and species-level consequences of competition in an } \\
\text { unproductive environment: an experimental approach using boreal forest } \\
\text { understory vegetation }\end{array}$ & $\mathrm{PhD}$ \\
\hline Gilbert, B. & 2008 & Notes on species coexistence, invasion and ecosystem function & $\mathrm{PhD}$ \\
\hline Marshall, C.B. & 2008 & $\begin{array}{l}\text { Effects of plant functional group removal on the soil microbial community } \\
\text { diversity and composition }\end{array}$ & MSc \\
\hline Knopp, A. & 2009 & $\begin{array}{l}\text { First step restoration techniques in invaded grassland in southern British } \\
\text { Columbia }\end{array}$ & MSc \\
\hline McLaren, J. & 2010 & $\begin{array}{l}\text { The influence of plant functional groups on ecosystem functions in a } \\
\text { grassland in northern Canada }\end{array}$ & $\mathrm{PhD}$ \\
\hline deKoning, $\mathrm{P}$. & 2011 & $\begin{array}{l}\text { Consequences and recovery after nutrient enrichment and herbivore } \\
\text { reduction in the boreal forest understory }\end{array}$ & MSc \\
\hline Carlyle, C.N. & 2012 & $\begin{array}{l}\text { Interacting effects of climate change and disturbance on grassland plants and } \\
\text { plant communities }\end{array}$ & $\mathrm{PhD}$ \\
\hline Grainger, T.N. & 2012 & $\begin{array}{l}\text { Winners and losers in a changing climate: Causes and consequences of } \\
\text { shifting vegetation dynamics after long-term nutrient enrichment in a } \\
\text { boreal forest understory }\end{array}$ & MSc \\
\hline
\end{tabular}


Table 1 continued

\begin{tabular}{|c|c|c|c|}
\hline Name & Year & Title & Degree \\
\hline DeSandoli, L. & 2013 & Restoration of plant communities to red-burned soils & $\mathrm{MSc}$ \\
\hline Lu, J. & 2013 & $\begin{array}{l}\text { The effects of litter quantity and quality on soil nutrients and litter } \\
\text { invertebrates in two contrasting forests of Southwestern China }\end{array}$ & MSc \\
\hline Harrower, W. & In progress & $\begin{array}{l}\text { Changes in trophic structure along a gradient of water availability in } \\
\text { temperate montane grasslands }\end{array}$ & $\mathrm{PhD}$ \\
\hline
\end{tabular}

Fig. 1 Poster advertising Roy Turkington's Symposium. The clover running man image courtesy of Derek Tan

\section{ROY TURKINGTON SYMPOSIUM}

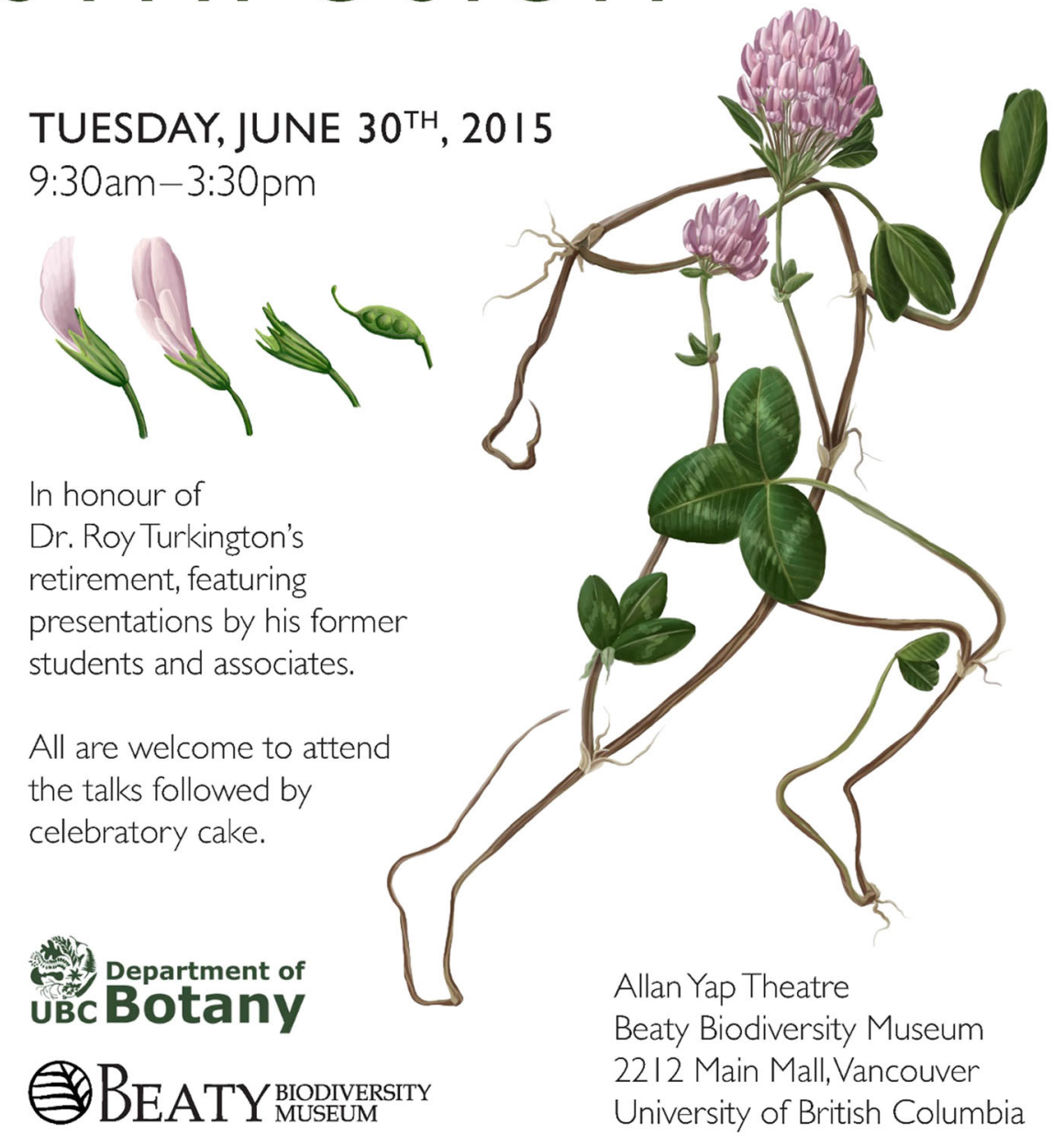

novel cost-benefit model for plant-plant interactions (Lortie et al. 2016). The fourth is an investigation of shifting plant geographic ranges (Jones and Gilbert 2016). The fifth paper investigates plant response of two grass species along a rainfall gradient (Dyer et al.
2016), the sixth is an investigation of root production in contrasting ecosystems (Balogianni et al. 2016), and the seventh and final paper of the first theme is a study of acorn dispersal, predation, and recruitment in Southwest China (Xia et al. 2016). 
To begin the second theme, the eighth paper is a test of plant functional groups on ecosystem properties (McLaren et al. 2016). The ninth paper investigates biotic and abiotic factors that control growth and survival of smooth brome (Carrigy et al. 2016). The tenth paper investigates the effects of litter quantity and quality on soil nutrients and litter invertebrates in a southern China oak forest ( $\mathrm{Lu}$ et al. 2016). The eleventh paper tests the effects of herbivore and litter on acorn germination and seedling survival in a Southwestern China forest (Hu et al. 2016), and the twelfth and final paper in the Special Issue investigates the impact of animal memory on seed dispersal (John et al. 2016).

\section{References}

Balogianni VG, Blume-Werry G, Wilson SD (2016) Root production in contrasting ecosystems: the impact of rhizotron sampling frequency. Plant Ecol 217:1359-1367. doi:10. 1007/s11258-016-0588-7

Carrigy AA, Stotz GC, Dettlaff MA, Pec GJ, Inderjit EN, Cahill JF Jr (2016) Community-level determinants of smooth brome (Bromus inermis) growth and survival in a Canadian savannah. Plant Ecol 217:1395-1413. doi:10.1007/ s11258-016-0642-5

Dyer AR, Woodward SJ, Petersen JE (2016) Response variation across a strong rainfall gradient in two naturalized annual grass species. Plant Ecol 217:1345-1355. doi:10.1007/ s11258-016-0590-0

Fraser LH, Garris W, Carlyle CN (2016) Predicting plant trait similarity along environmental gradients. Plant Ecol 217:1297-1306. doi:10.1007/s11258-016-0628-3

Givnish TJ (1988) Adaptation to sun and shade: a whole-plant perspective. Australian Journal of Plant Physiology 15:63-92

Güsewell S (2004) N: P ratios in terrestrial plants: variation and functional significance. New Phytol 164:243-266

Harper JL (1967) A Darwinian approach to plant ecology: presidential address, British Ecological Society. J Ecol 55:247-270

Hu J, Luo C, Turkington R, Zhou Z (2016) Effects of herbivores and litter on Lithocarpus hancei seed germination and seedling survival in the understorey of a high diversity forest in SW China. Plant Ecol 217:1429-1440. doi:10. 1007/s11258-016-0610-0

John EA, Soldati F, Burman OHP, Wilkinson A, Pike TW (2016) Plant ecology meets animal cognition: impacts of animal memory on seed dispersal. Plant Ecol 217:1441-1456. doi:10.1007/s11258-016-0652-3

Jones NT, Gilbert B (2016) Biotic forcing: the push-pull of plant ranges. Plant Ecol 217:1331-1344. doi:10.1007/s11258016-0603-z

Lortie CJ, Filazzola A, Welham C, Turkington R (2016) A costbenefit model for plant-plant interactions: a density-series tool to detect facilitation. Plant Ecol 217:1315-1329. doi:10.1007/s11258-016-0604-y

Lu J, Turkington R, Zhou Z (2016) The effects of litter quantity and quality on soil nutrients and litter invertebrates in the understory of two forests in southern China. Plant Ecol 217:1415-1428. doi:10.1007/s11258-016-0600-2

MacDougall AS, Turkington R (2005) Are invasive species the drivers or passengers of ecological change in highly disturbed plant communities? Ecology 86:42-55

McLaren JR, Novoplansky A, Turkington R (2016) Few effects of plant functional group identity on ecosystem properties in an annual desert community. Plant Ecol 217:1379-1393. doi:10.1007/s11258-016-0660-3

Stamp N (2003) Out of the quagmire of plant defense hypotheses. Q Rev Biol 78:23-55

Sternberg M (2016) From America to the Holy Land: disentangling plant traits of the invasive Heterotheca subaxillaris (Lam.) Britton \& Rusby. Plant Ecol 217:1307-1314. doi:10.1007/s11258-016-0656-z

Turkington R (2009) Obituary: Professor John L. Harper FRS CBE, 1925-2009. J Ecol 97:835-837

Turkington R, Harper JL (1979) The growth, distribution and neighbour relationships of Trifolium repens in a permanent pasture. IV. Fine-scale biotic differentiation. J Ecol 67:245-254

Turkington R, Mehrhoff LA (1990) The role of competition in structuring pasture communities. In: Grace JB, Tilman D (eds) Perspectives on plant competition. Academic Press, New York, pp 307-340

Weltzin JF, Loik ME, Schwinning S, Williams DG, Fay PA, Haddad BM, Harte J, Huxman TE, Knapp AK, Lin G, Pockman WT, Shaw RM, Small EE, Smith MD, Smith SD, Tissue DT, Zak JC (2003) Assessing the response of terrestrial ecosystems to potential changes in precipitation. Bioscience 53:941-952

Xia K, Tan H, Turkington R, Hu J, Zhou Z (2016) Desiccation and post-dispersal infestation of acorns of Quercus schottkyana, a dominant evergreen oak in SW China. Plant Ecol 217:1369-1378. doi:10.1007/s11258-016-0654-1 